Tersedia online di: http://ejournal-balitbang.kkp.go.id/index.php/JP
e-mail:jurnalpari@gmail.com
JURNAL PARI
Volume 5 Nomor 2 Desember 2019
p-ISSN: 2502-0730
e-ISSN : 2549-0133

\title{
DINAMIKA PUBLIKASI KARYA TULIS ILMIAH (KTI) PENELITI BBRLPP 2015-2018
}

\author{
Ketut Masiani \\ Balai Besar Riset Budidaya Laut dan Penyuluhan Perikanan, Gondol \\ Diterima tanggal : 23 Juli 2019 Diterima setelah perbaikan : 24 September 2019 \\ disetujui terbit : 19 November 2019
}

\begin{abstract}
ABSTRAK
Karya tulis ilmiah merupakan kekayaan intelektual bagi suatu lembaga dan negara dan secara individu merupakan media aktualisasi diri seorang peneliti. Di lembaga riset hasil karya tulis ilmiah merupakan salah satu point yang sering dipersyaratkan dalam keberhasilan pencapaian kinerja lembaga. BBRBLPP sebagai lembaga riset di bawah naungan BRSDMKP merupakan sebuah lembaga riset dalam bidang budidaya laut. Karya tulis ilmiah yang dihasilkan oleh peneliti banyak digunakan sebagai indikator keberhasilan lembaga untuk memperoleh suatu pengakuan dari lembaga lain. Untuk mengetahui perkembangan KTI yang dihasilkan dilakukan inventarisasi capaian KTI yang telah dipublikasikan oleh peneliti BBRBLPP dari tahun 2015-2018. Hasil menunjukkan bahwa jumlah KTI yang dipublikasikan dalam periode tahun 2015 - 2018 terbanyak terjadi pada tahun 2016 yaitu sebanyak 71 judul dan terendah pada tahun 2017 sebanyak 27 judul. Rata - rata jumlah KTI yang dihasilkan per peneliti pada tiap kelompok penelitian yang tertinggi ada pada kelti nutrisi dan teknologi pakan yaitu sebanyak $6 \mathrm{KTI}$ dan terendah pada kelti kesehatan ikan dan lingkungan sebanyak $4 \mathrm{KTI}$.
\end{abstract}

KATA KUNCI : Karya tulis ilmiah; peneliti; publikasi.

\section{ABSTRACT}

Scientific papers is an institution and state intellectual property and individually is a media of self-actualization of a researcher. In research institutions the numbers of its are one of the points that are often required in the successful achievement of the institution's performance. IMRAFE as a research institute under the auspices of Agency for Marine \& Fisheries Research \& Human Resources is a research institute in the field of marine aquaculture. Scientific papers produced by researchers are widely used as indicators of the success of the Institute to obtain recognition from other institutions. To find out the development of paper produced in a period of 2015-2018, an inventory of published paper was made. The results show that the highest number of published papers in the period of 2015 - 2018 occurred in 2016 at 71 titles and the lowest in 2017 as many as 27 titles. The highest average number of papers produced per researcher in each study group was in the nutrition and feed technology as much as 6 titles and the lowest was in fish health and environmental as much as 4 titles.

KEYWORDS: Publications; researchers; scientific papers. 


\section{PENDAHULUAN}

Karya Tulis ilmiah merupakan salah satu kekayaan intelektual bagi suatu lembaga dan negara. Publikasi ilmiah berperan sebagai media aktualisasi diri para peneliti dalam pengembangan ilmu pengetahuan baik tingkat nasional maupun internasional (Ansor, 2017). Selain itu karya tulis ilmiah yang dimuat dalam jurnal/ publikasi internasional berperan meningkatkan harga diri suatu negara dalam bentuk diplomasi mutu pendidikan dan ilmu pengetahuan.

Di lembaga pemerintahan terutama lembaga riset hasil karya tulis ilmiah merupakan salah satu poin yang sering dipersyaratkan dalam pengukuran keberhasilan pencapaian kinerja Lembaga. Balai Besar Riset Budidaya Laut dan Penyuluhan Perikanan (BBRBLPP) adalah Lembaga riset di bawah naungan Badan Riset Sumber Daya Manusia Kelautan dan Perikanan (BRSDMKP) yang merupakan sebuah lembaga riset dalam bidang budidaya laut. Seperti yang tercantum dalam Peraturan Menteri Kelautan dan Perikanan Republik Indonesia Nomor 22/PermenKP/2017 tentang organisasi dan Tata Kerja Balai Besar Riset Budidaya Laut dan Penyuluhan Perikanan disebutkan bahwa BBRBLPP mempunyai tugas melaksanakan riset budidaya laut dan penyuluhan perikanan dimana dalam melaksanakan tugas memiliki fungsi:

a) penyusunan rencana program dan anggaran, pemantauan, evaluasi, dan laporan,

b) pelaksanaan riset budidaya laut di bidang biologi, reproduksi, genetika, bioteknologi, nutrisi dan teknologi pakan, pathologi, ekologi dan lingkungan budidaya laut, serta pengembangan teknologi budidaya laut,

c) pelayanan teknis, jasa, informasi, komunikasi, dan kerja sama riset budidaya laut,

d) penyusunan materi, metodologi, pelaksanaan penyuluhan perikanan, serta pengembangan dan fasilitasi kelembagaan dan forum masyarakat bagi pelaku utama dan pelaku usaha,

e) penyusunan kebutuhan peningkatan kapasitas penyuluh Pegawai Negeri Sipil (PNS), swadaya, dan swasta,

f) pengelolaan prasarana sarana riset budidaya laut dan penyuluhan perikanan,

g) pelaksanaan urusan tata usaha dan rumah tangga.

Salah satu indikator pencapaian kinerja BBRBLPP adalah keberhasilan kegiatan riset yang dilakukan oleh peneliti yang dibuktikan dalam bentuk karya tulis ilmiah yang telah dipublikasikan. Karya tulis ilmiah yang dihasilkan oleh peneliti banyak digunakan sebagai indikator keberhasilan lembaga untuk memperoleh suatu pengakuan dari lembaga lain.
Beberapa kegiatan yang menuntut pencapaian karya tulis ilmiah yang dihasilkan peneliti diantaranya kegiatan dalam rangka mewujudkan dan mempertahankan BBRBLPP sebagai lembaga pusat unggulan iptek (PUI) bidang perbenihan budidaya laut, mewujudkan lembaga menuju lembaga WBK dan WBBM, Penilaian KNAPP, laporan tahunan balai, laporan kinerja lembaga, bahan buku media kkp, laporan Aset Tak Berwujud (ATB) dan sebagai data dukung beberapa kegiatan pelaporan lainnya. Pentingnya keberadaan KTI menuntut BBRBLPP untuk terus meningkatkan jumlah KTI yang dihasilkan oleh peneliti.

Pentingnya keberadaan karya tulis ilmiah ini menuntut pengelola perpustakaan yang bertugas sebagai pengelola koleksi untuk melakukan pengolahan koleksi perpustakaan yang dapat dilakukan dengan mengumpulkan, mengkoleksi, menyimpan, melayankan/menyebarkan karya tulis ilmiah. Untuk mengetahui berbagai karya tulis ilmiah yang telah dihasilkan oleh peneliti, pengelola perpustakaan perlu melakukan inventarisasi karya tulis ilmiah. Kegiatan inventarisasi ini selain untuk mengetahui karya tulis ilmiah yang telah dipublikasikan juga untuk membuat database karya tulis ilmiah sehingga mempermudah dalam penelusuran informasi karya tulis ilmiah, serta pemanfaatan lainnya terkait karya tulis ilmiah. Untuk mengetahui perkembangan KTI yang dihasilkan oleh peneliti penulis mencoba untuk menginventarisir capaian KTI yang telah dipublikasikan oleh peneliti BBRBLPP dari tahun 2010-2018. Harapan penulis dengan adanya analisis ini dapat menjadi informasi bagi BBRBLPP terkait jumlah KTI peneliti BBRBLPP yang telah dipublikasikan sehingga dapat mengambil kebijakan terkait publikasi KTI.

\section{TINJAUAN PUSTAKA}

Perpustakaan BBRBLPP merupakan perpustakaan khusus yang berada dibawah unit kerja BBRBLPP. Menurut Surachman (2005) perpustakaan khusus merupakan perpustakaan yang didirikan untuk mendukung visi dan misi lembaga-lembaga khusus dan berfungsi sebagai pusat informasi khusus terutama berhubungan dengan penelitian dan pengembangan. Lebih rinci fungsi perpustakaan khusus dipaparkan buku Badan Standarisasi Nasional-SNI7496:2009 yaitu:

a. Mengembangkan koleksi yang dapat menunjang kinerja lembaga induknya,

b. Menyimpan semua terbitan dari dan tentang lembaga induknya,

c. Menjadi focal point untuk informasi terbitan lembaga induknya,

d. Menjadi pusat referal dalam bidang yang sesuai 
dengan lembaga induknya,

e. Mengorganisasikan materi perpustakaan,

f. Mendayagunakan koleksi,

g. Menerbitkan literature sekunder dan tersier dalam lembaga induknya, baik cetak maupun elektronik,

h. Menyelenggarakan pendidikan pengguna,

i. Menyelenggarakan kegiatan literasi informasi untuk pengembangan kompetensi sumber daya manusia lembaga induknya,

j. Melestarikan materi perpustakaan materi preventif maupun kuratif,

k. Ikut serta dalam kerjasama perpustakaan serta jaringan perpustakaan,

I. Menyelenggarakan otomasi perpustakaan,

$\mathrm{m}$. Melaksanakan digitalisasi materi perpustakaan,

n. Menyajikan layanan koleksi digital,

o. Menyediakan akses informasi pada tingkat lokal, nasional, regional dan global.

Dari pedoman ini perpustakaan BBRBLPP merupakan perpustakaan yang memiliki tugas dan fungsi mendukung kegiatan BBRBLPP, yaitu menyediakan koleksi untuk memenuhi kebutuhan pemustaka yang didominasi oleh peneliti serta mengelola koleksi yang salah satunya adalah karya tulis ilmiah yang dihasilkan peneliti.

\section{Karya Tulis IImiah}

Pada perpustakaan khusus karya tulis ilmiah merupakan salah satu koleksi yang banyak dibutuhkan oleh pemustaka sehingga karya tulis ilmiah merupakan salah satu bahan pustaka yang layak dijadikan koleksi pada sebuah perpustakaan. Hal ini sesuai dengan Undang-Undang Republik Indonesia Nomor 43 Tahun 2007 tentang Perpustakaan dimana pada bab I pasal 1 ayat 2 disebutkan "koleksi perpustakaan adalah semua informasi dalam bentuk karya tulis, karya cetak, dan/atau karya rekam dalam berbagai media yang mempunyai nilai pendidikan, yang dihimpun, diolah, dan dilayankan. Secara detail sebagaimana tertuang pada Peraturan Kepala Lembaga IImu Pengetahuan Indonesia Nomor 04/E/ 2012 Tentang Pedoman Karya Tulis IImiah bahwa Karya tulis ilmiah (KTI) adalah tulisan hasil litbang dan/atau tinjauan, ulasan (review), kajian, dan pemikiran sistematis yang dituangkan oleh perseorangan atau kelompok yang memenuhi kaidah ilmiah.

Karya tulis ilmiah yang dipublikasikan oleh peneliti merupakan salah satu karya tulis yang dibuat secara sistematika dari hasil penelitian yang dilakukan. Dalam karya tulis ilmiah ini termuat informasiinformasi penting hasil riset yang telah diujicobakan dalam kegiatan penelitiannya. Banyak informasi yang berguna untuk pengembangan ilmu pengetahuan dan sebagai sumber inovasi untuk kegiatan penelitian lainnya. Keberadaan karya tulis ilmiah ini sangat penting tidak hanya untuk peneliti tetapi juga untuk teknisi sebagai pembantu pelaksanaan riset dan juga oleh pemustaka lain seperti mahasiswa, masyarakat pelaku usaha perikanan ataupun instansi pemerintah lainnya.

Dalam dunia penelitian karya tulis ilmiah merupakan bagian yang tidak dapat dipisahkan mengingat karya tulis ilmiah merupakan salah satu bentuk otentik hasi dari kegiatan penellitian yang dilakukan oleh peneliti dan sebagai bentuk pertanggungjawaban kepada publik tehadap penelitian yang dilakukan. Karya tulis ilmiah tidak hanya diperlukan dalam sosialisasi hasil penelitian, tetapi juga menentukan profesionalisme (Junandi, 2018). Karya tulis ilmiah yang dihasilkan oleh peneliti dapat menunjukkan kualitas dan kemampuan seorang peneliti itu sendiri. Sebagai peneliti kegiatan riset merupakan tugas utama dan hasil riset yang telah dilakukan wajib dipubikasikan dalam bentuk KTI sehingga segala ilmu yang dihasilkan dapat diketahui dan dimanfaatkan oleh orang lain. Dengan hal ini kegiatan-kegiatan riset yang dilakukan oleh peneliti dan hasil KTI yang telah berhasil dipublikasikan mengindikasikan keaktifan dari seorang peneliti. Seperti yang diungkapkan oleh Royani (2010) bahwa peneliti yang aktif adalah peneliti yang melaksanakan kegiatan penelitian dengan hasil yang dapat dilihat melalui $\mathrm{KTI}$ yang ditulisnya. Pernyataan ini menggambarkan bahwa KTI memiliki arti penting bagi peneliti sebagai bukti kerberhasilan seorang peneliti dalam menjalankan tugas dan perannya. Secara rinci Kurniawan (2017) menyebutkan beberapa alasan karya tulis ilmiah itu penting diantaranya:

1. Karya tulis ilmiah merupakan salah satu bentuk hasil riset yang dilakukan peneliti,

2. Merupakan media untuk pengembangan dan penyebaran ilmu pengetahuan yang terbarukan (transfer of knowledge),

3. Karya tulis ilmiah merupakan media untuk pembaharuan hasil penemuan,

4. Media untk berbagi (sharing) pemikiran /ide-ide,

5. Sarana untuk mendiseminasikan hasil penelitian kepada orang lain,

6. Sebagai bentuk pertanggungjawaban kepada publik,

7. Sebagai foster etos bagi peneliti yaitu menjadikan peneliti sebagai produsen bidang ilmu pengetahuan.

Dari uraian diatas dapat dikatakan bahwa karya tulis ilmiah merupakan media untuk menyampaikan hasil-hasil pemikiran dari hasil penelitian yang 
dilakukan oleh peneliti yang dapat menjadi sumber informasi dan inspirasi bagi orang lain. Untuk dapat dimanfaatkan oleh orang lain, kegiatan yang tidak kalah penting terhadap hasil publikasi KTI ini adalah pengelolaan KTI. Pengelolaan KTI ini memegang peranan penting dalam penyebaran informasiinformasi yang termuat dalam KTI. Pengelolaan KTI ini meliputi kegiatan pendataan (inventarisasi) sampai dengan penyebaran publikasi KTI sehingga informasi yang dikandungnya dapat tersampaikan kepada masyarakat/pemustaka.

\section{Inventarisasi}

Inventarisasi merupakan salah satu kegiatan yang penting dalam pengelolaan dan pengembangan koleksi perpustakaan. Dengan melakukan inventarisasi ini pengelola perpustakaan dapat mengetahui koleksi yang dimiliki baik terkait jumlah koleksi, topik/subyek koleksi maupun perkembangan kondisi koleksi. Secara harfiah dalam Kamus Besar Bahasa Indonesia (KBBI) disebutkan inventarisasi adalah pencatatan atau pengumpulan data (tentang kegiatan, hasil yang dicapai, pendapat umum, persuratkabaran, kebudayaan, dan sebagainya). Dalam dunia perpustakaan inventarisasi koleksi adalah suatu kegiatan pencatatan setiap bahan pustaka yang diterima oleh suatu perpustakaan ke dalam buku induk atau buku inventaris perpustakaan menyangkut semua data bibliografi yang sesuai dengan kebutuhan pelaporan dan database, sebagai tanda bukti perbendaharaan atau pemilikan perpustakaan (Fitriani, 2016). Secara umum manfaat dan tujuan inventarisasi perpustakaan adalah untuk mengetahui jumlah, komposisi, dan keberadaan koleksi perpustakaan, sehingga mempermudah dalam penelusuran dan pemanfaatannya. Qalyubi (2007) menyatakan bahwa dengan kegiatan inventarisasi akan mempermudah dalam membuat statistik dan laporan tentang beberapa hal yaitu:

1. jumlah bahan pustaka yg dimiliki perpustakaan,

2. jumlah judul dan eksemplarnya,

3. jumlah judul dan eksemplarnya berdasarkan bahasa,

4. jumlah buku fiksi, buku teks, buku referensi, dan lain-lain,

5. jumlah penambahan bahan pustaka setiap tahun, dan

6. jumlah anggaran yang dikeluarkan.
Dengan kegiatan inventarisasi ini akan sangat membantu pengelola perpustakaan untuk mengetahui koleksi yang dimilikinya sehingga dapat mengoptimalkan pelayanan terhadap pemustaka dan dapat mempermudah penelusuran dan pengumpulan data untuk data dukung pelaporan perpustakaan dan pelaporan lainnya.

\section{METODE}

\section{Sumber Data}

Sumber data merupakan asal data yang digunakan. Data yang digunakan dalam analisis ini berasal dari data primer dan sekunder. Data primer yang digunakan diantaranya data KTI yang dihasilkan peneliti dari tahun 2015-2018 yang termuat pada jurnal dan prosiding yang terkoleksi di perpustakaan BBRBLPP. Sedangkan data sekunder diperoleh melalui studi pustaka/studi literatur dalam bentuk tercetak maupun online.

\section{Teknik Pengumpulan dan Analisis Data}

Dalam analisis ini data karya tulis ilmiah yang dihasilkan oleh peneliti BBRBLPP yang dipublikasikan pada jurnal dan prosiding yang terbit tahun 2015-2018 dikumpulkan terlebih dahulu. Data yang telah terkumpul kemudian dilakukan analisa. Analisa data dilakukan berdasarkan tahun terbit, bidang penelitian dan jenis media publikasi.

\section{Penyajian Data}

Hasil data yang telah dianalisis kemudian disajikan dalam bentuk tabel yang memuat informasi bidang penelitian, jenis publikasi dan hasil analisa. Selain dalam bentuk tabel hasil analisis juga disajikan dalam bentuk grafik.

\section{PEMBAHASAN}

Salah satu jenis koleksi yang ada di perpustakaan BBRBLPP adalah karya tulis ilmiah yang dihasilkan oleh peneliti BBRBLPP. Berdasarkan renstra BBRBLPP 2015-2019 jumlah peneliti BBRBLPP sebanyak 37 orang yang terbagi dalam 4 kelompok kegiatan strategis penelitian yaitu genetik, breeding dan bioteknologi, nutrisi dan teknologi pakan, pengembangan teknologi budidaya, kesehatan ikan dan lingkungan budidaya dengan sebaran sebagai berikut: 
Tabel 1. Sebaran peneliti berdasarkan kelompok penelitian (Kelti)

\begin{tabular}{|l|l|c|}
\hline No & Kelompok Penelitian (Kelti) & Jumlah \\
\hline 1 & Genetik, breeding dan bioteknologi & 8 \\
\hline 2 & Nutrisi dan teknologi pakan & 5 \\
\hline 3 & Teknik dan teknologi akuakultur & 17 \\
\hline 4 & Kesehatan ikan dan lingkungan & 7 \\
\hline & Total & $\mathbf{3 7}$ \\
\hline
\end{tabular}

Sebagaimana terlihat pada tabel 1 jumlah peneliti BBRBLPP yang berada dalam kelompok penelitian (kelti) teknik dan teknologi akukultur adalah yang terbanyak, diikuti oleh peneliti pada kelti genetik breeding dan bioteknologi, kelti kesehatan ikan dan lingkungan dan paling sedikit pada kelti nutrisi dan teknologi pakan secara berturut - turut sebanyak 17 , 8,7 , dan 5 peneliti.

Setiap tahun peneliti BBRBLPP menghasilkan beberapa karya tulis yang dipublikasikan pada jurnal dan prosiding serta majalah. KTI yang telah dihasilkan tersebut merupakan salah satu koleksi yang dimiliki oleh perpustakaan BBRBLPP. Untuk mengetahui penyebaran dan jumlah karya tulis ilmiah peneliti BBRBLPP pengelola perpustakaan melakukan inventarisasi terhadap KTI yang sudah dipublikasikan. Hasil inventarisasi menunjukkan bahwa karya tulis ilmiah peneliti BBRBLPP dipublikasikan ke beberapa media dalam bentuk jurnal dan prosiding. Publikasi di dalam negeri, selain di lingkup Kementerian Kelautan dan Perikanan karya tulis ilmiah peneliti juga diterbitkan di perguruan tinggi. Jumlah publikasi karya tulis ilmiah yang dihasilkan peneliti BBRBLPP tahun 2015-2018 dapat dilihat pada grafik di bawah ini

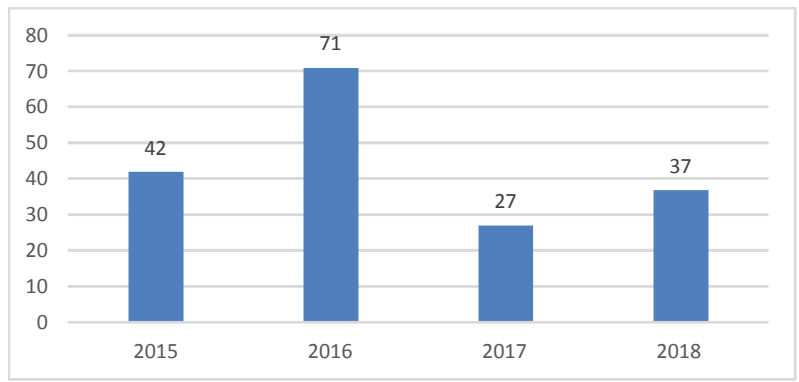

Gambar 1. Grafik Jumlah Publikasi KTI peneliti BBRBLPP tahun 2015-2018

Gambar 1 menunjukkan bahwa jumlah KTI yang dihasilkan oleh peneliti BBRBLPP berfluktuasi yaitu pada tahun $2015 \mathrm{KTI}$ yang telah dipublikasikan/ dihasilkan oleh peneliti sebanyak 42 judul, tahun 2016 sebanyak 71 judul, tahun 2017 sebanyak 27 judul dan pada tahun 2018 menghasilkan 37 judul KTI. Jumlah KTI yang dipublikasikan dalam periode tahun 2015 - 2018 terbanyak terjadi pada tahun 2016 yaitu sebanyak 71 judul dan terendah pada tahun 2017 sebanyak 27 judul.

Berdasarkan dari kelompok penelitiannya karya tulis ilimiah yang dihasilkan peneliti dapat dijabarkan dalam tabel 2.

Tabel 2. Jumlah Tulisan yang dihasilkan peneliti berdasarkan kelompok Penelitian tahun 2015-2018

\begin{tabular}{|c|c|c|c|c|}
\hline Tahun & $\begin{array}{c}\text { Genetik, breeding dan } \\
\text { Bioteknologi }\end{array}$ & $\begin{array}{c}\text { Nutrisi dan Teknologi } \\
\text { Pakan Ikan }\end{array}$ & $\begin{array}{c}\text { Teknik dan } \\
\text { Teknologi } \\
\text { Akuakultur }\end{array}$ & $\begin{array}{c}\text { Kesehatan Ikan } \\
\text { dan Lingkungan }\end{array}$ \\
\hline 2015 & 13 & 13 & 14 & 2 \\
\hline 2016 & 13 & 9 & 38 & 11 \\
\hline 2017 & 8 & 3 & 13 & 3 \\
\hline 2018 & 6 & 7 & 14 & 10 \\
\hline Jumlah & $\mathbf{4 0}$ & $\mathbf{3 2}$ & $\mathbf{7 9}$ & $\mathbf{2 6}$ \\
\hline
\end{tabular}

Dari tabel 2 di atas terlihat bahwa jumlah KTI yang dihasilkan masing-masing kelompok penelitian dari tahun 2015-2018 yaitu, kelompok Genetik, breeding dan Bioteknologi menghasilkan 40 judul KTI, Nutrisi dan Teknologi Pakan Ikan menghasilkan 32 judul, Teknik dan Teknologi Akuakultur menghasilkan 79 judul, Kesehatan Ikan dan Lingkungan menghasilkan 26 judul KTI.

Persentase jumlah KTI yang dihasilkan peneliti berdasarkan kelompok Penelitian tahun 2015-2018 dapat dilihat dalam gambar2. 


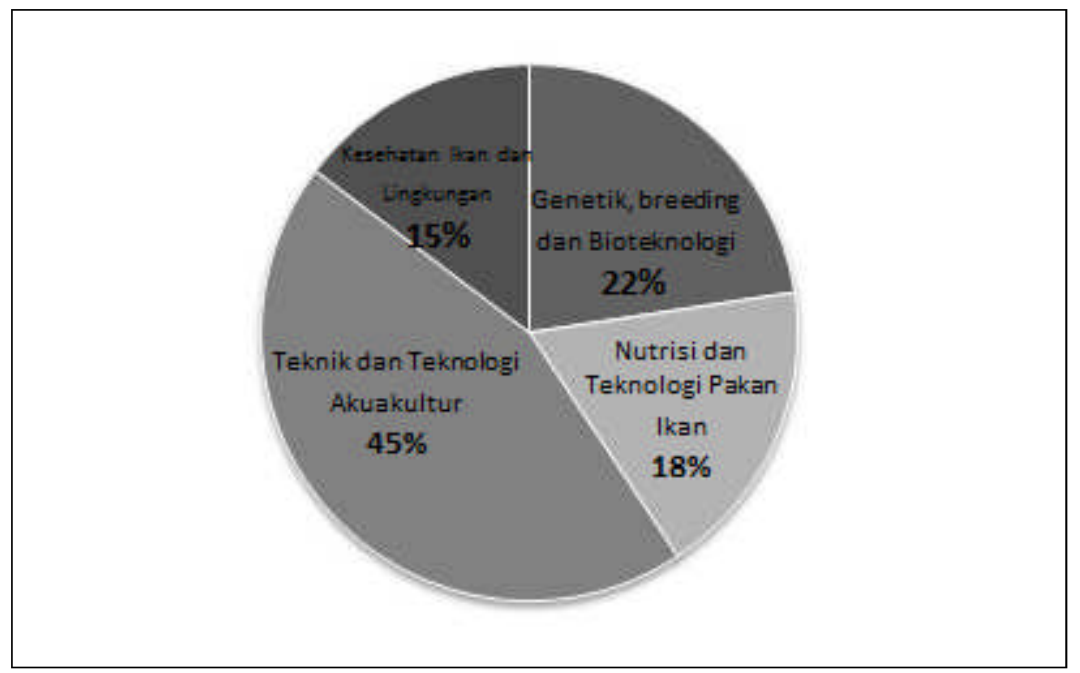

Gambar 2. Prosentase hasil KTI tahun 2015-2018 berdasarkan kelompok penelitian

Gambar 2 mengambarkan jumlah kontribusi KTI peneliti berdasarkan kelompok penelitian yang ada di BBRBLPP. Dari keseluruhan KTI yang terpublikasi tahun 2015-2018 jumlah KTI tertinggi hingga terendah dihasilkan dari Kelti Teknik dan Teknologi akuakultur, kelti Genetik, breeding dan Bioteknologi, kelti Nutrisi dan Teknologi Pakan Ikan, dan kelti Kesehatan Ikan dan Lingkungan secara berturut turut sebanyak $45 \%$, $22 \%, 18 \%$ dan $15 \%$.

Tabel 3 menunjukkan bahwa berdasarkan sebaran jenis publikasinya terlihat bahwa jumlah $\mathrm{KTI}$ tahun
2015-2018 yang diterbitkan dalam jurnal dan prosiding yaitu kelompok Genetik, breeding dan Bioteknologi dimuat dalam jurnal sebanyak 24 judul dan prosiding 16 Judul , Nutrisi dan Teknologi Pakan Ikan dimuat dalam jurnal sebanyak 7 judul dan prosiding 25 Judul, Teknik dan Teknologi Akuakultur dimuat dalam jurnal sebanyak 21 judul dan prosiding 58 Judul, dan untuk Kesehatan Ikan dan Lingkungan dimuat dalam jurnal sebanyak 10 judul dan prosiding 16 Judul KTI. Jumlah $\mathrm{KTI}$ yang dimuat dalam jurnal dan prosiding tahun 2015-2018 dapat dilihat dalam gambar 3 .

Tabel 3. Sebaran Publikasi berdasarkan Jenis Publikasi tahun 2015-2018

\begin{tabular}{|c|c|c|c|c|c|c|c|c|}
\hline \multirow{2}{*}{ Tahun } & \multicolumn{2}{|c|}{$\begin{array}{c}\text { Genetik, breeding } \\
\text { dan Bioteknologi }\end{array}$} & $\begin{array}{c}\text { Nutrisi dan Teknologi } \\
\text { Pakan Ikan }\end{array}$ & $\begin{array}{c}\text { Teknik dan Teknologi } \\
\text { Akuakultur }\end{array}$ & \multicolumn{2}{c|}{$\begin{array}{c}\text { Kesehatan Ikan dan } \\
\text { Lingkungan }\end{array}$} \\
\cline { 2 - 9 } & Jurnal & Prosiding & Jurnal & Prosiding & Jurnal & Prosiding & Jurnal & Prosiding \\
\hline 2015 & 6 & 7 & 2 & 11 & 3 & 11 & 1 & 1 \\
\hline 2016 & 6 & 7 & 1 & 8 & 7 & 31 & 2 & 9 \\
\hline 2017 & 6 & 2 & 0 & 3 & 7 & 6 & 3 & 0 \\
\hline 2018 & 6 & 0 & 4 & 3 & 4 & 10 & 4 & 6 \\
\hline Jumlah & $\mathbf{2 4}$ & $\mathbf{1 6}$ & $\mathbf{7}$ & $\mathbf{2 5}$ & $\mathbf{2 1}$ & $\mathbf{5 8}$ & $\mathbf{1 0}$ & $\mathbf{1 6}$ \\
\hline
\end{tabular}

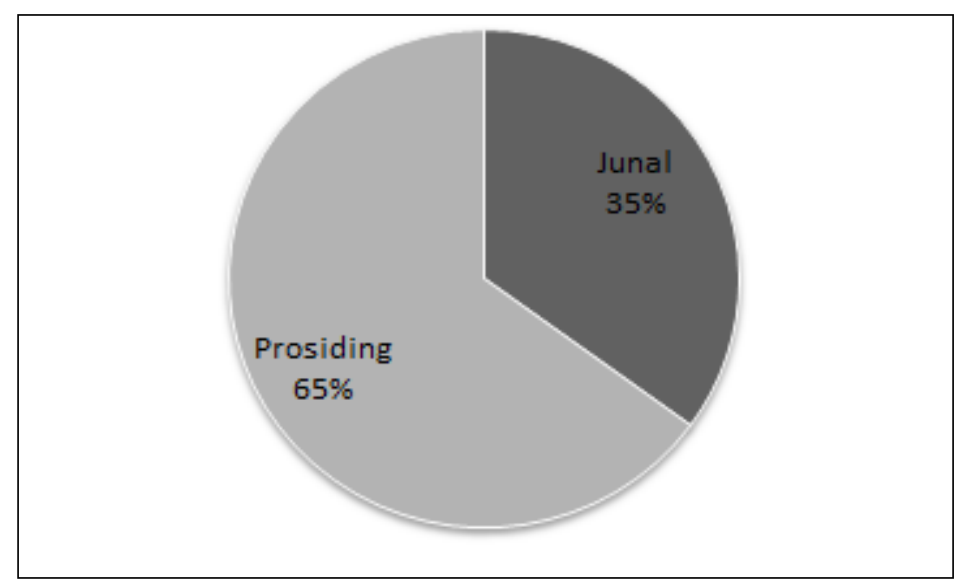

Gambar 3. Perbandingan/Prosentase hasil KTI berdasarkan jenis media publikasi tahun 2015-2018 
Dari gambar 3 terlihat bahwa dari tahun 2015-2018 persentase jumlah $\mathrm{KTI}$ yang dihasilkan oleh peneliti BBRBLPP yang dipublikasikan dalam bentuk prosiding lebih banyak jika dibandingkan dengan yang dipublikasikan dalam media jurnal yaitu sebanyak $65 \%$ berbanding 35\%.
Dari jumlah keseluruhan peneliti dan karya tulis ilmiah yang telah dipublikasikan tahun 2015-2018 dapat juga diketahui jumlah rata-rata tulisan yang dihasilkan oleh peneliti BBRBLPP pada tiap kelompok penelitiannya.

Tabel 3. Rata-rata jumlah tulisan yang dihasilkan peneliti per kelompok penelitian pada periode tahun 20152018

\begin{tabular}{|l|c|c|c|}
\hline \multicolumn{1}{|c|}{ Kelompok Peneliti } & Jumlah Peneliti & Jumlah KTI & Rerata \\
\hline Genetik, breeding dan Bioteknologi & 8 & 40 & 5 \\
\hline Nutrisi dan Teknologi Pakan & 5 & 32 & 6 \\
\hline Teknik dan Teknologi Akuakultur & 17 & 79 & 5 \\
\hline Kesehatan Ikan dan Lingkungan & 7 & 26 & 4 \\
\hline
\end{tabular}

Tabel 3 menunjukkan bahwa rata - rata jumlah KTI yang dihasilkan peneliti BBRBLPP pada periode tahun 2015 hingga 2018 dalam kelti genetik breeding dan bioteknologi, kelti nutrisi dan teknologi pakan, kelti Teknik dan teknologi akuakultur dan kelti kesehatan ikan dan lingkungan secara berturut- turut sebanyak 5, 6,5 dan $4 \mathrm{KTI}$. Rerata jumlah $\mathrm{KTI}$ yang dihasilkan per peneliti tertinggi ada pada kelti nutrisi dan teknologi pakan yaitu sebanyak $6 \mathrm{KTI}$ dan terendah pada kelti kesehatan ikan dan lingkungan sebanyak $4 \mathrm{KTI}$.

\section{KESIMPULAN}

Karya Tulis ilmiah merupakan kekayaan intelektual bagi suatu lembaga dan negara dan secara individu merupakan media aktualisasi diri seorang peneliti. Hasil inventarisasi dan analisa KTI yang telah dipublikasikan oleh peneliti BBRBLPP dari tahun 2015-2018 menunjukkan dinamika jumlah KTI yang dipublikasikan dalam periode tahun 2015 - 2018. Publikasi KTI terbanyak terjadi pada tahun 2016 dan terendah pada tahun 2017. Jumlah KTI yang dihasilkan peneliti pada tiap kelompok penelitian berbeda-beda, dengan rata - rata jumlah KTI yang dihasilkan peneliti tertinggi ada pada kelti nutrisi dan teknologi pakan dan terendah pada kelti kesehatan ikan dan lingkungan.

\section{DAFTAR PUSTAKA}

Peraturan Menteri Kelautan dan Perikanan Republik Indonesia Nomor 22/PermenKP/2017 tentang organisasi dan Tata Kerja Balai Besar Riset Budidaya Laut dan Penyuluhan Perikanan. http://jdih.kkp.go.id/peraturan/ 22\%20PERMEN-KP\%202017.pdf Diakses tanggal 10 Juni 2019
Peraturan Kepala Lembaga IImu Pengetahuan Indonesia Nomor 04/E/2012 Tentang Pedoman Karya Tulis IImiah (http:// pusbindiklat.lipi.go.id/wp-content/uploads/PerkaLIPI-No-4E2012-ttg-KTI.pdf Diakses tanggal 10 Juni 2019

Undang-Undang Republik Indonesia Nomor 43 Tahun 2007 tentang Perpustakaan.

http://ppid.perpusnas.go.id/upload/regulasi/094607UU No 43 tahun 2007 tentang Perpustakaan.pdf Diakses tanggal 10 Juni 2019

Ansor, S., 2017, Studi Meta Analisis Strategi dan Pemanfaatan Jurnal Elektronik (e - journals) untuk Mahasiswa Lulusan Universitas Negeri Malang dalam Upaya Publikasi IImiah Bereputasi Internasional. Record And Library Journal Volume 3, Nomor 1, Januari-Juni 2017. Surabay: UNAIR.

https://e-journal.unair.ac.id/RLJ/article/download/ 7292/4426 Diakses tanggal 13 Juni 2019

Badan Standardisasi Nasional.2009. Perpustakaan khusus instansi pemerintah. Jakarta. Badan Standardisasi Nasional

BBRBLPP. 2018. Rencana Strategis tahun 2015-2019 Gondol: BBRBLPP

Fitriani. R.E. 2016. Metode "EF" untuk Menentukan Nomor Inventaris Buku di Perpustakaan Universitas Lampung : Studi Kasus Pengadaan Buku Tahun 2012 dan 2013 . Record And Library Journal Volume 2, Nomor 1, Januari - Juni 2016. Lampung: Universitas Lampung. 
file.upi.edu/Direktori/FIP/...PERPUSTAKAAN.../ Inventarisasi makalah 2009.pdf Diakses tanggal 12 Juni 2019

Inventarisasi.(n.d). Kamus Besar Bahasa Indonesia (KBBI) Kamus versi online/daring (dalam jaringan). https://kbbi.web.id/inventarisasi Diakses tanggal 14 Juni 2019

Junandi, S. 2018. Keterpakaian dan relevansi Jurnal Agritech sebagai rujukan artikel jurnal ilmiah internasional terindeks Scopus. Jurnal Kajian Informasi \& Perpustakaan Vol. 6, No. 1 (Juni 2018) 95-108.

jurnal.unpad.ac.id/jkip/article/download/15066/8256 Diakses tanggal 10 Juni 2019

Kurniawan, A. 2019. 7 Pengertian, Tujuan Dan Manfaat Karya IImiah Menurut Para Ahli.https:// www.gurupendidikan.co.id/6-pengertian-tujuandan-manfaat-karya-ilmiah-menurut-para-ahli/ Diakses tanggal 10 Juni 2019

Qalyubi, S., dkk. 2007. Dasar-Dasar I/mu Perpustakaan dan Informasi. Yogyakarta: Jurusan Ilmu Perpustakaan dan Informasi (IPI) Fakultas Adab UIN Sunan Kalijaga.

Royani, Y., 2010. Pemetaan karya tulis ilmiah Ipnk: studi kasus LIPI dan BPPT (2004-2008).Makalah workshop pemaparan hasil kajian Pusat Dokumentasi dan Informasi IImiah-LIPI. Jakarta.LIPI

Surachman, A. 2005. Pengelolaan Perpustakaan Khusus http://eprints.rclis.org/8633/1/ Manajemen Perpustakaan Khusus.pdf. Diakses tanggal 12 Juni 2019 